$\underline{\text { Avicenna Journal of Nursing and Midwifery Care - ISSN 2676-5748 }}$

\title{
The Effect of Mentorship Program on Self-Esteem, Anxiety and Learning Clinical Skills of Emergency Medical Students: A Randomized Controlled Trial
}

\author{
Hamideh Mashalchi ${ }^{1}$, Ferdos Pelarak ${ }^{2}$, Somayeh Mahdavi Kian ${ }^{3}$, Tayebeh Mahvar ${ }^{3}$, Amin Abdolvand ${ }^{4}$, \\ Morteza Habibi Moghadam ${ }^{*}$
}

1. Department of Nursing, School of Nursing and Midwifery, Dezful University of Medical Sciences, Dezful, Iran

2. Department of Nursing, Dezful Branch, Islamic Azad University, Dezful, Iran

3. Department of Nursing, School of Nursing and Midwifery, Kermanshah University of Medical Sciences, Kermanshah, Iran

4. Student Research Committee, Dezful Branch, Islamic Azad University, Dezful, Iran

5. Department of Anesthesiology, School of Paramedical Sciences, Dezful University of Medical Sciences, Dezful, Iran

\begin{tabular}{lll}
\hline Article Info & ABSTRACT \\
\hline
\end{tabular}

Received: 2020/08/24;

Accepted: 2020/10/25;

Published Online: 2021/09/21

10.30699/ajnmc.29.3.210

Original Article

Use your device to scan and read the article online

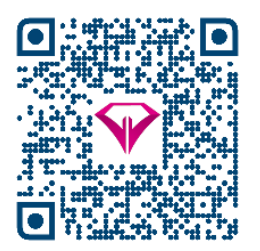

Introduction: Clinical education (mentorship program) is one of the most important aspects of education in the medical sciences. Therefore, this study was conducted to investigate the effect of mentorship program on self-esteem, anxiety and learning clinical skills of emergency medical students.

Methods: This study was a quasi-experimental study in which 24 emergency medical students of Dezful University of Medical Sciences were enrolled by available sampling. Data collection scales were Coopersmith Self-Esteem Inventory, Spielberger State-Trait Anxiety Inventory and Clinical Skills Questionnaire. Data analysis was performed using SPSS-20 software and descriptive and analytical statistics.

Results: In this study, $70.8 \%$ of students (17 persons) got an average point of $15-17$ and were 21 years old. Also, the mean scores of self-esteem $(P$ value $<0.001)$, anxiety $(P$ value $<0.001)$ and clinical skills $(P$ value $<0.001)$ before and after clinical training were significantly different so that the mean of self-esteem, anxiety and clinical skills of students before Clinical education were $37.12,90.29$ and 112.29 , followed by $46.92,70.50$ and 136 , respectively.

Conclusion: After using the mentorship program, an increase in clinical skills, a decrease in anxiety and an increase in students' self-esteem were observed. Therefore, it is necessary to develop a clinical education program that provides a path for scientific growth to acquire clinical competencies.

Keywords: Clinical education, Mentoring, Self-esteem, Anxiety, Clinical skills, Student, Medical emergencies
Corresponding Information:

Morteza Habibi Moghadam, Department of Anesthesiology, School of Paramedical Sciences, Dezful University of Medical Sciences, Dezful, Iran. Email: habibi.morteza94@gmail.com

Copyright $\odot$ 2021, This is an original open-access article distributed under the terms of the Creative Commons Attribution-noncommercial 4.0 International License which permits copy and redistribution of the material just in noncommercial usages with proper citation.

How to Cite This Article:

Mashalchi H, Pelarak F, Mahdavi Kian S, Mahvar T, Abdolvand A, Habibi Moghadam M. The effect of Mentorship Program on Self-Esteem, Anxiety and Learning Clinical Skills of Emergency Medical Students: A Randomized Controlled Trial. Avicenna J Nurs Midwifery Care. 2021; 29 (3) :210-219 
بررسى تأثير روش منتورشيٍ بر ميزان عزتنفس، اضطراب و مهارتهاى بالينى دانشجويان رشتهُ فوريتهاى

$$
\text { يزشكى - يك مطالعة كار آزمايى بالينى }
$$

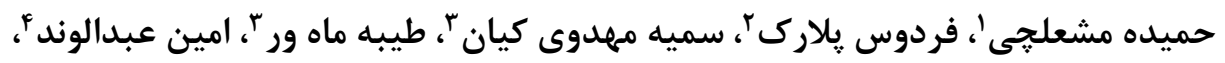 \\ مر تضى حبيبى مقدم}

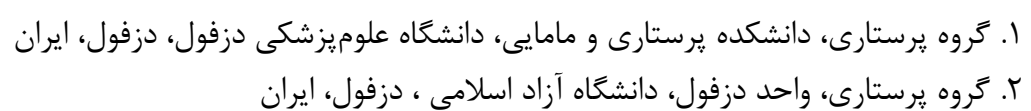

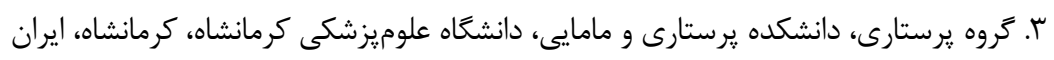

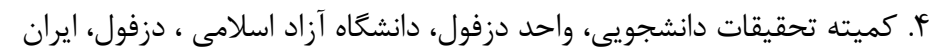

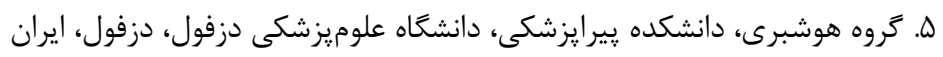

קكيده

مقدمه: مدل منتورشيٍ يكى از مهمترين جنبههاى آموزش در رشتههاى علوميزشكى است و

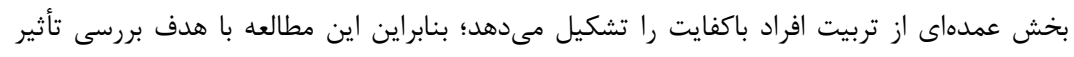

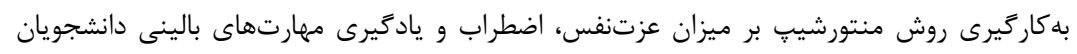

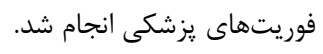
روش كار: اين مطالعه يك مطالعه كارآزمايى بالينى بود كه بf دانش دانشجو آقا و سال آخر رشته

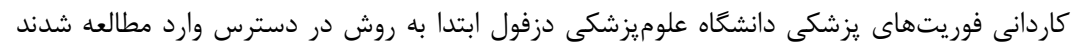

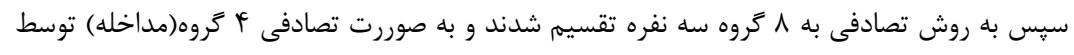

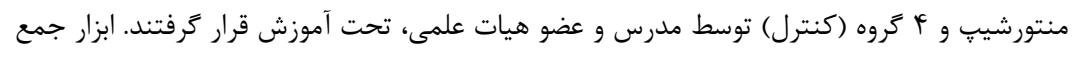

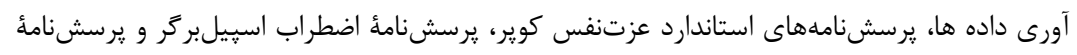

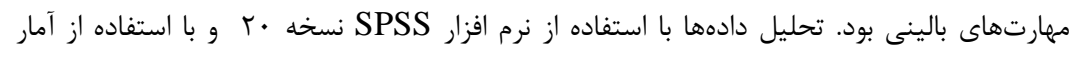

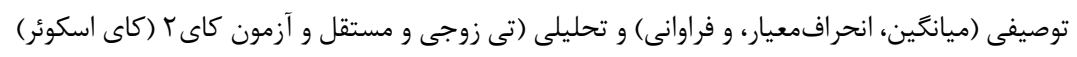

$$
\text { مورد بر سىى قرار گرفتند. }
$$

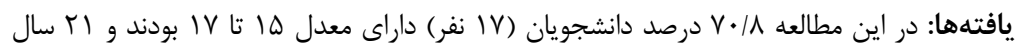

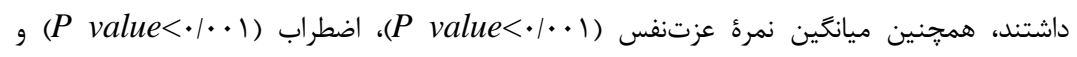

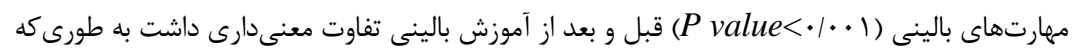

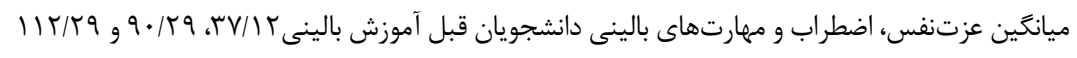

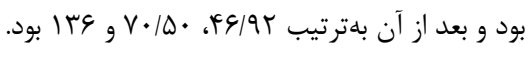

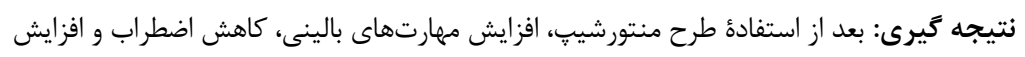

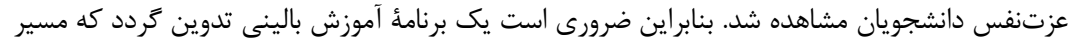

$$
\text { رشد علمى جهت كسب توانايىهاى بالينى فراهم شود. }
$$

اطلاعات مقاله

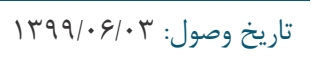

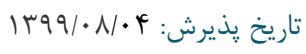

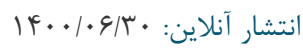

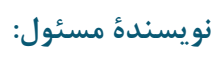

مر تضى حبيبى مقدم

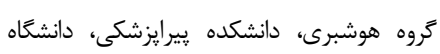
علوميزشكى دزفول، دزفول، ايران

يست الكترونيك:

Habibi.morteza94@gmail.com

براى دانلود اين مقاله، كد زير را با موبايل خود اسكن كنيد.

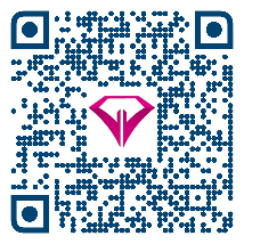

بررسىها نشان داد فارغالتحصيلان رشتهُ فوريتهاى يزشكى

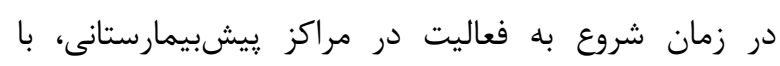
جالشهاى بسيارى مواجه هستند كه يكى از مهرمترين دلايل

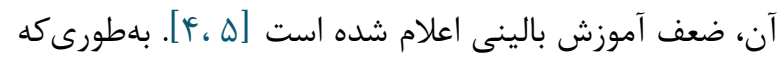

اولين جزء نظام مراقبت، مراقبتهاى يِيشبيمارستانى

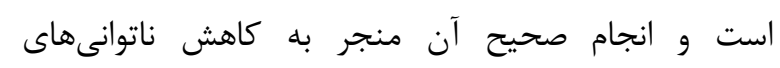
طولانىمدت و مرى و مير مىشود [ [ ]. براى انجام صحيح اين

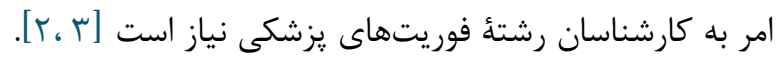


با توجه به كوتاهبودن دوره تحصيل دانشجويان مقطع كاردانى رشتهٔ فوريتهاى يزشكى و فرصت محدود آنها براى كسب صلاحيتهاى لازم درخصوص مهارتهاى بالينى يايه و نظر به اينكه فارغ التحصيلان فوريتهاى يزشكى وظيفه امدادرسانى و مراقبت سريع از بيماران اورزانسى، مصدومان

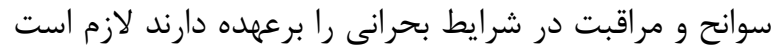

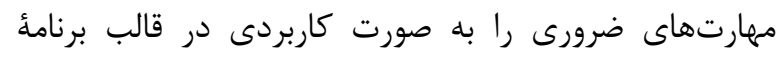
آموزش بالينى منظم توسط يك مربى بالينى (منتورشيب) در طول دوره تحصيل آموزش ببينند. در سالهاى اخير مدلهاى مختلفى براى ارتقاى كيفيت آموزش بالينى دانشجويان اردائه

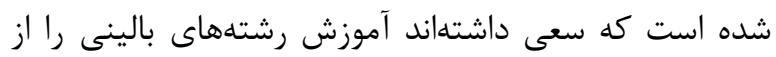

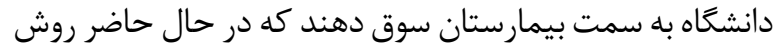
آموزش بالينى در رشته يرستارى در حال انجام است.

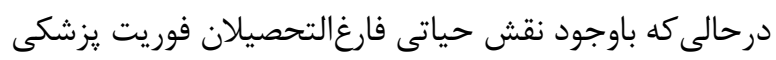
در جامعه و اهميت اين رشته در مراقبت از بيماران در شرايط

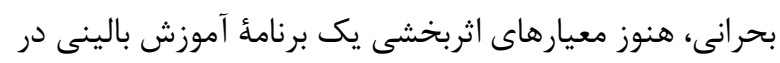

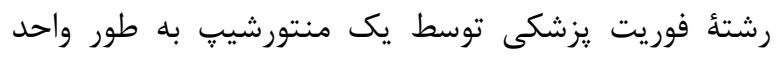
مشخص نيست [ع] و در مطالعات مختلف نيز توافق كاملى در مورد عوامل اثركذار بر آموزش بالينى دانشجويان در دسترس دئس

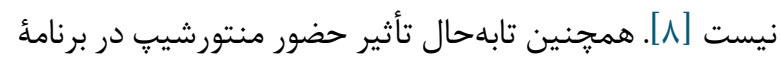

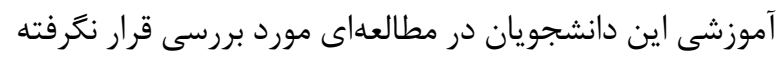

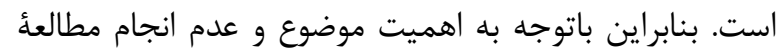

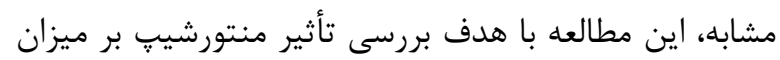
عزتنفس، اضطراب و يادكيرى مهارتهاى بالينى دانشجويان فوريتهاى يزشكى دانشگاه علوميزشكى دزفول انجام شده

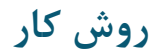

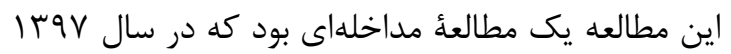

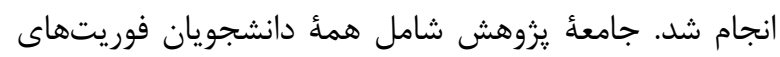

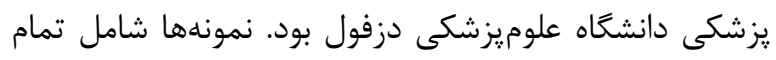
دانشجويان ترم سوم رشتأ فوريتهاى يزشكى بود دان

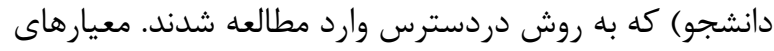

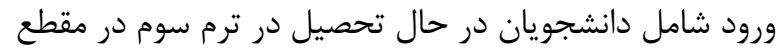
كاردانى، عدم كذراندن كارآموزى ييشبيمارئن براى شركت در مطالعه بود. تكميل ناقص يرسشنامهها و عدم رضايت به ادامٔ همكارى سبب خروج نمونهها از مطالعه
بررسىها نشان داد ضعف آموزش بالينى منجر به كاهش كارايى نظام آموزشى، مهارتهاى بالينى و كيفيت خدمات به

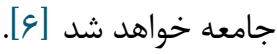

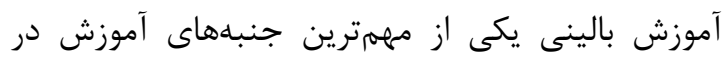

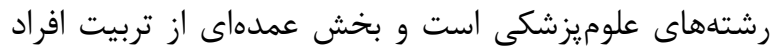

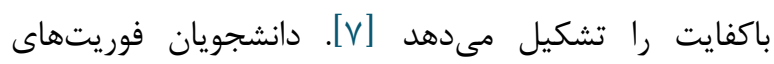

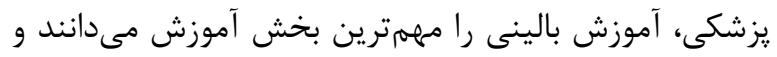
بيشترين مشكلات و نارضايتىها را در ارتباط با با آن بيان مىكنند. اين دانشجويان بيشتر مواقع، بر بالين بيمار دجار

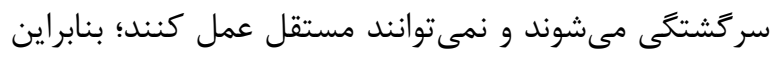

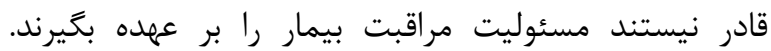
مهممترين دلايل اين امر را مىتوان به ناهماهنكى بين دروس

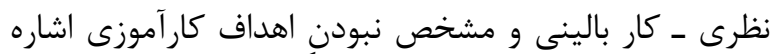

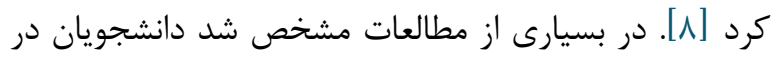
حين كار بالين، از خود مطمئن نيستند و همين مسئله مانع از از

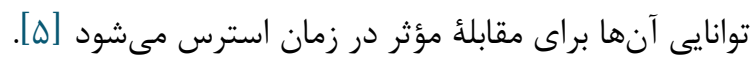

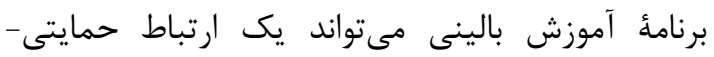

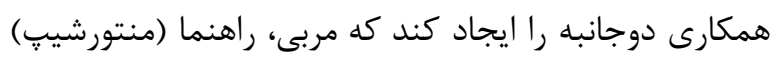

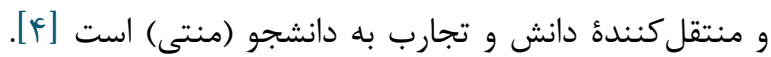

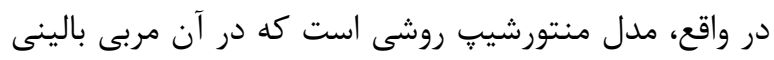

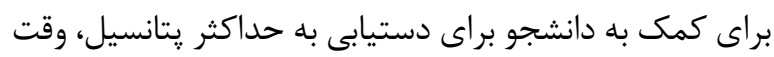

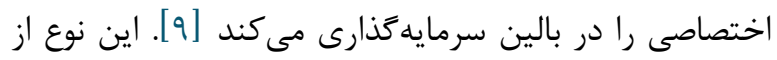

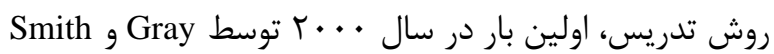

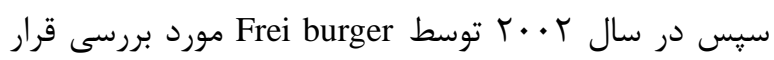
كرفت و يكى از شيوههاى آن، استفاده از مشاركت و همكارى دانشجويان سطوح بالاتر و مربيان در طى تجربيات بالينى اوليه

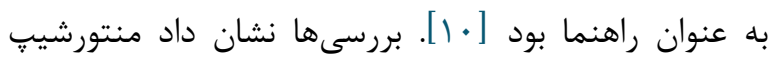

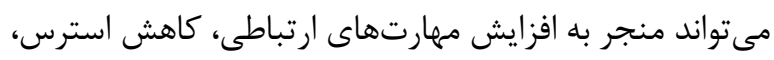
افزايش اعتماد به نفس، دانش، مسئوليتيذيرى و توسعه حل

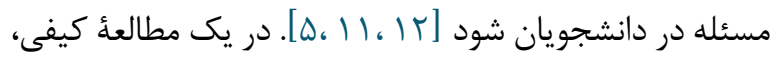

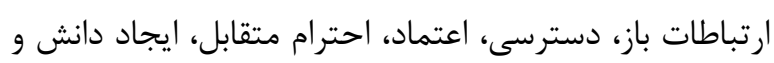

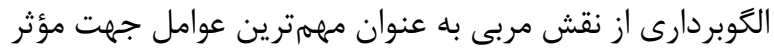

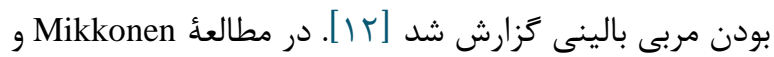

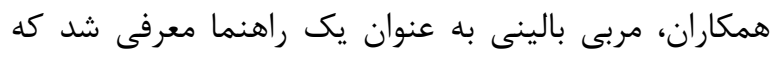

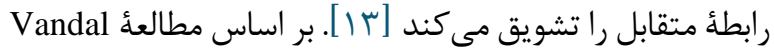
و همكاران، منتورشيب مىتواند منجر به افزايش بيشرفت

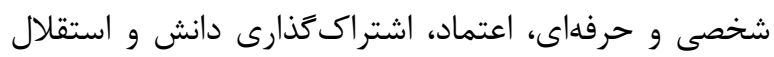
دانشجويان شود [11]]. 
يرسشنامئ مهارتهاى بالينى با بهرهيرى از مطالعات

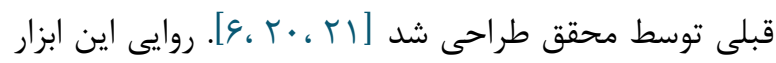

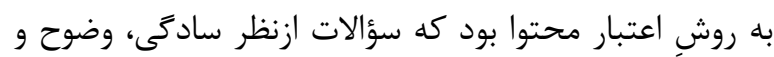
مرتبط بودن بررسى شد و يايايى آن به روش آلآ آلفاى كرونباخ،

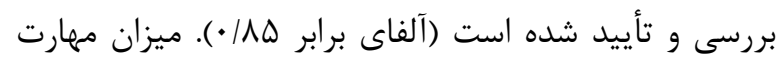

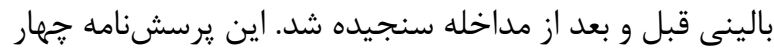

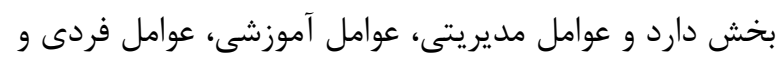

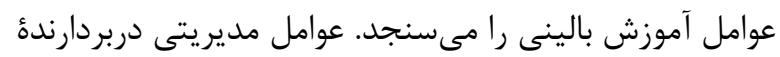
حيطههايى نقش برسنل، نقش مربى و انضباط آموزشى است.

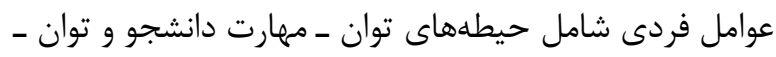

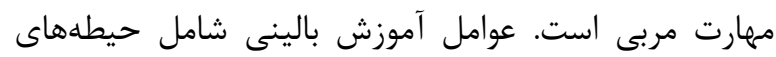

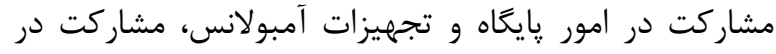

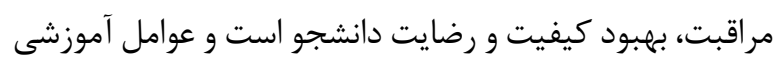

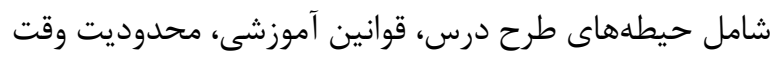

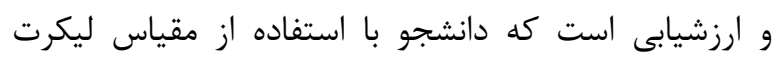

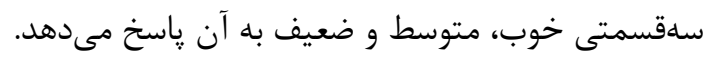

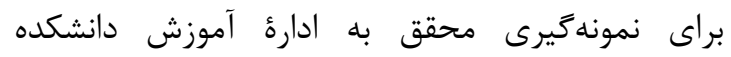

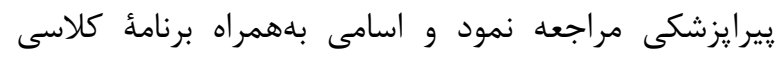
دانشجويان فوريت يزشكى را دريافت نمود، سيس بر اساس

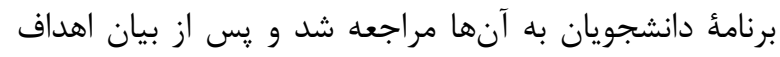
مطالعه و كسب رضايتكتبى آكاهانه، نسبت نمونه كيرى اقدام كرديد. محيط يزوهش در اين مطالعه، پايخاههاى فوريتهاى يزشكى شهر دزفول بود كه به عنوان مهمترين مراكز

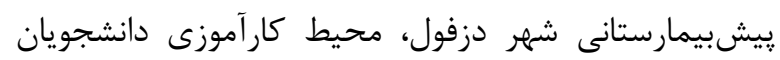
رشتأ فوريتهاى يزشكى در طى دوره تحصيل هستند. به دليل

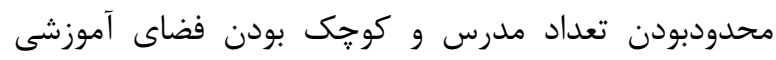

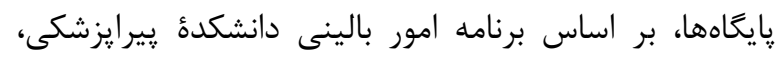

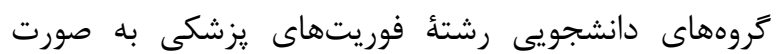

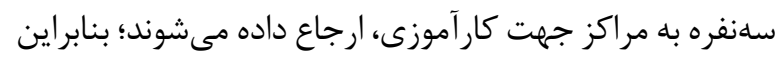

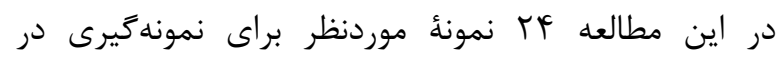

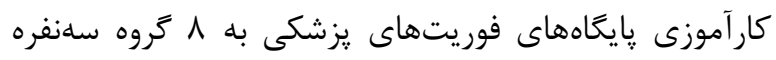

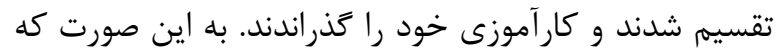

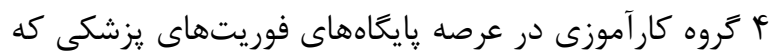

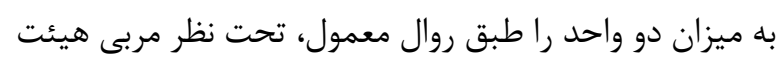

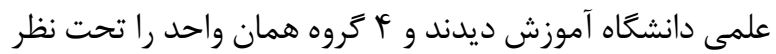
يك دانشجوى ترم ع رشته كارشناسى فوريتها بز

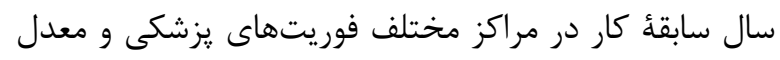

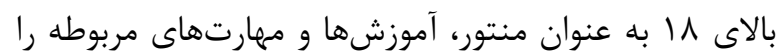

ابزار مطالعه شامل يرسشنامة اطلاعاتفردى، يرسشنامة

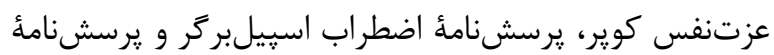

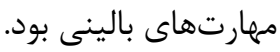

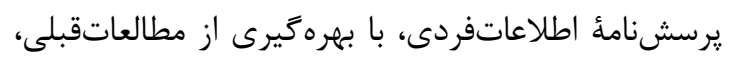

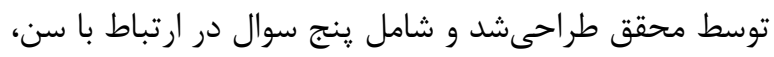

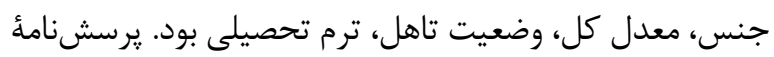

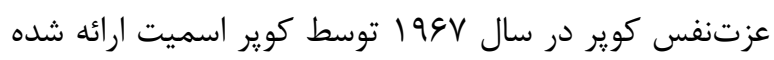

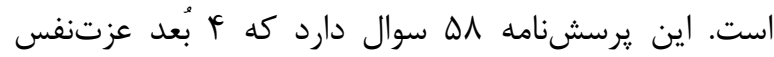
تحصيلى، خانوادگى، اجتماعى و عمومى را مىسنجد و \ سوال

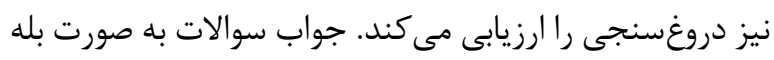

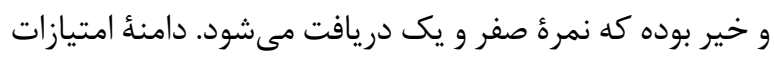
بُعد عزتنفس تحصيلى، خانوادگى، اجتماعى صفر تا 1 و و

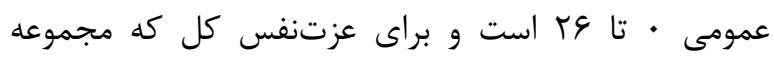

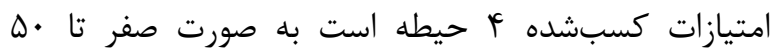
امتيازدهى مى كردد. در صورتى كه واحدهاى مورد يزوهش، از

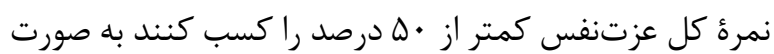

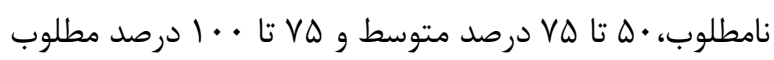
در نظر كرفته مىشود. روانسنجى ابزار عزتنفس كوير اسميت

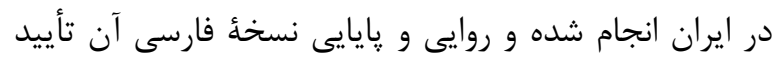

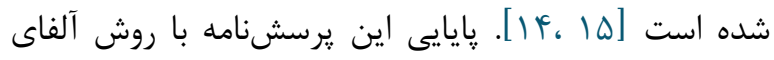

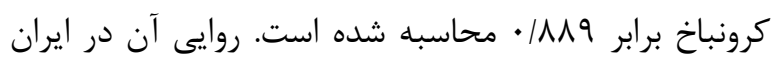

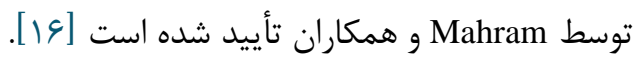
يرسشنامة اضطراب اسِيلبركر از • F سوال تشكيل شده

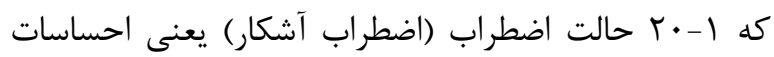
فرد را در "اين لحظه و زمان باسخكويى" ارزشيابى مى كند.

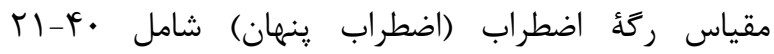

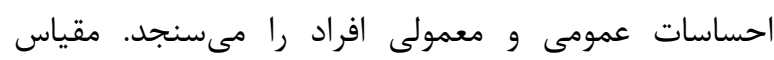

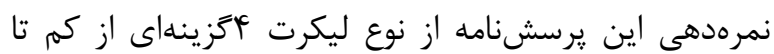

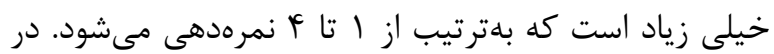

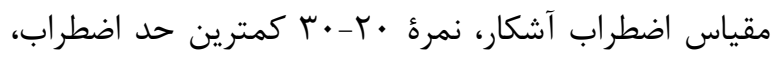
اضط خ Fr-r اضطراب شديد را نشان مىدهد. در مقياس اضطراب ينهان،

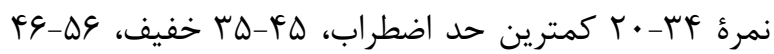
اضطراب متوسط و هV و بيشتر اضطراب شديد راب را نشان مى دهد. در مطالعة Khanipoor و همكاران ضريب همسانى

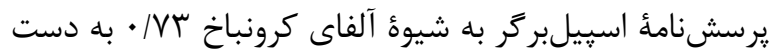

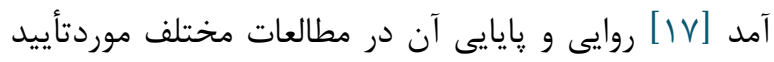

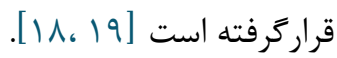

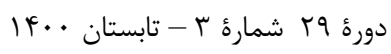




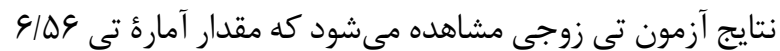

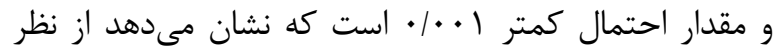

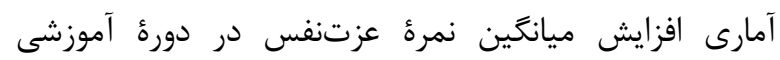

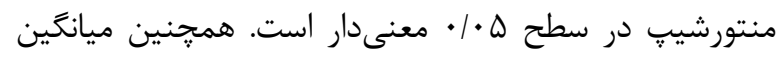
نمرة اضطراب نمونهها در زمانهاى قبل و بعد از آموزش بهترتي

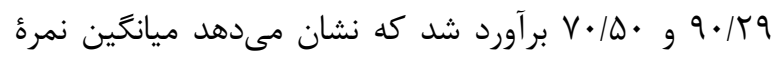

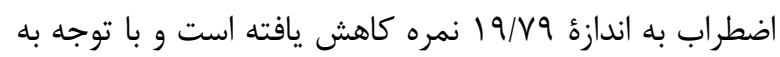

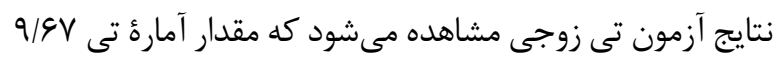

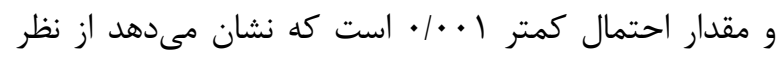

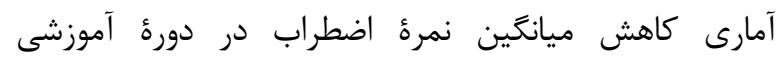
منتورشيب در سطح ه • • معنى دار است. ميانكين نمرهٔ مهارت

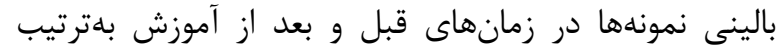

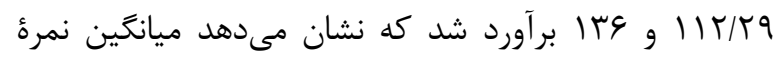

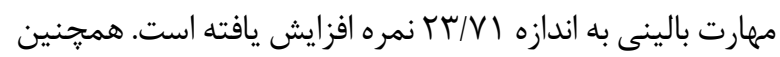

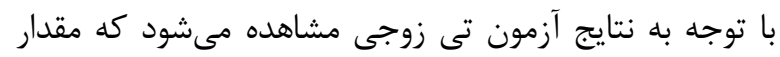

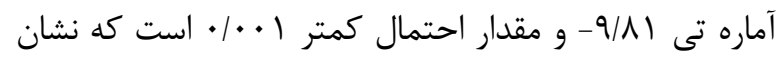

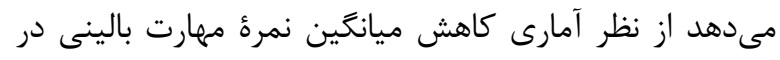

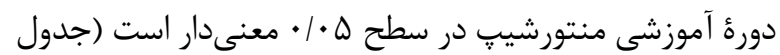

ميانكَين نمره عزتنفس بعد از دورههاى آموزش مربى و

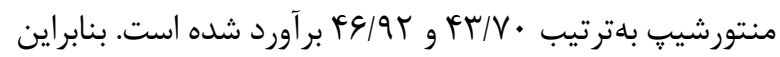
ميانكين نمرهٔ عزتنفس دانشجويان بعد از آموزش با مربى كمتر

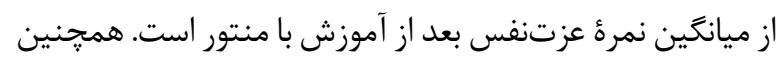

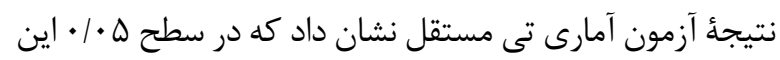

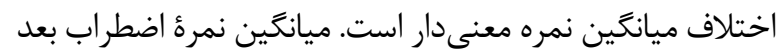

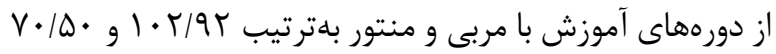

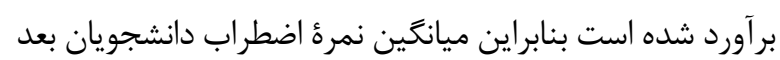

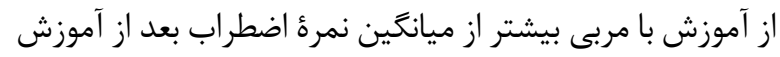
با منتور است. همجنين نتيجة آزمون آمارى تى مستقل نشان إنى داد كه در سطح ه • • اين اختلاف ميانخين نمره معنى دار است.

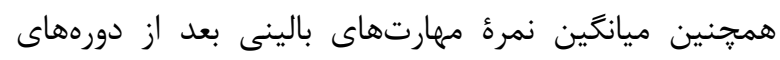

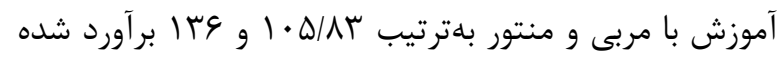

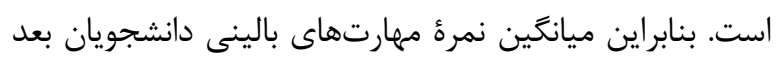

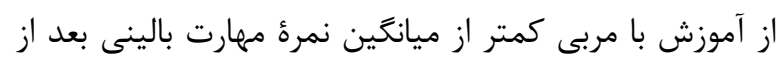

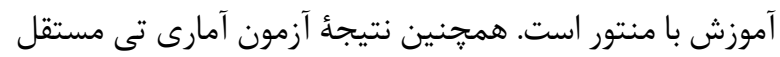

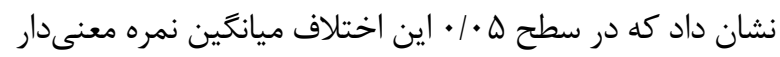

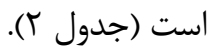

آموزش ديدند. لازم به ذكر است قبل از آموزش و در روز آخر

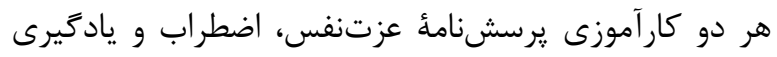
مهارتهاى بالينى توسط دانشجويان تكميل شد. تحليل دادهها

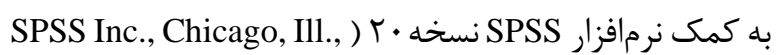

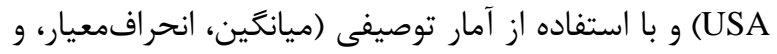

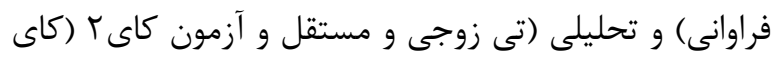

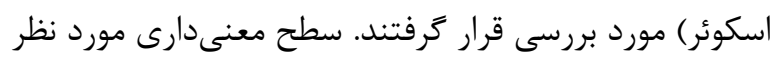
در اين مطالعه كمتر از هـ • • • بود.

\section{ملاحظات اخلاقى}

معاون تحقيقات فناورى دانشعاه علوميزشكى دزفول اين

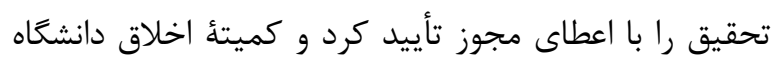
علوميزشكى دزفول، يروتكل مطالعه را با شماره مرجع

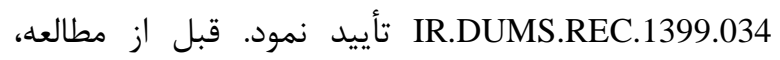
اهداف و روشها براى همدٔ شركت كنندكان توضيح داده شد و به آنها اطمينان داده شد كه ياسخها محرمانه خواهد ماند.

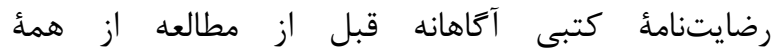
شركت كنند كان كرفته شده است.

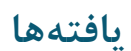

در اين مطالعه از بين TV دانشجوى ترم سوم رشتهٔ

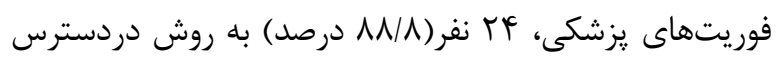

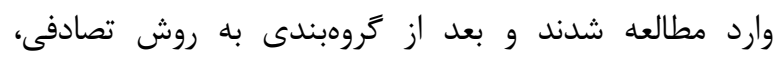

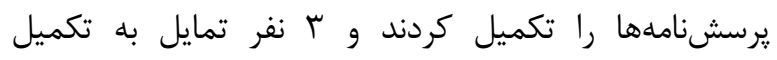

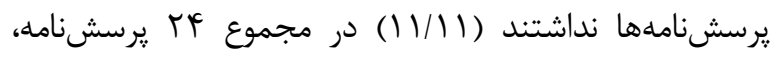

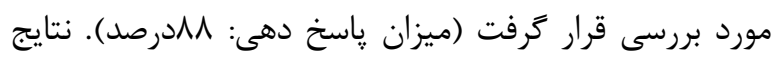

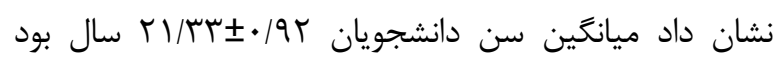

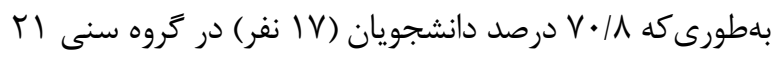

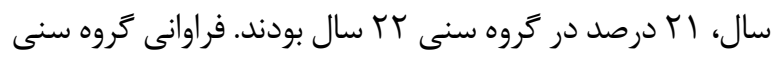

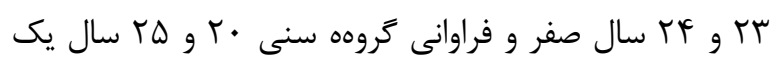

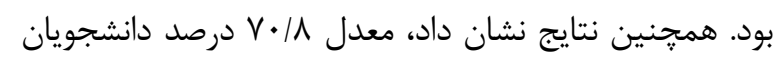

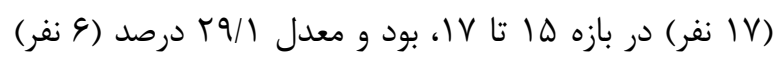

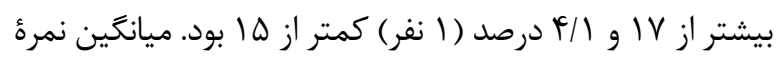

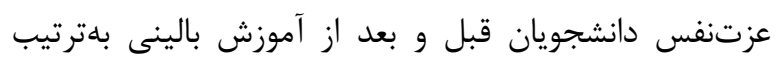

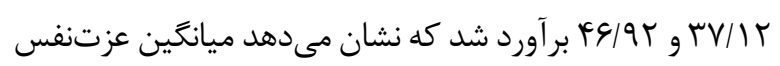

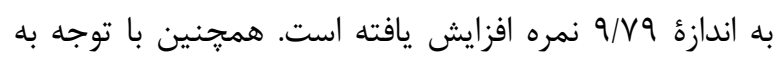


جدول ا. تعيين و مقايسه ميانغين نمره عزت نفس،اضطراب و مهارت هاى بالينى با استفاده از آزمون تى زوجى

\begin{tabular}{|c|c|c|c|c|c|}
\hline نتيجه آزمون & انحراف معيار & اختلاف ميانَين & انحراف معيار & ميانگَين & \\
\hline \multirow[t]{3}{*}{$\begin{array}{c}\mathrm{T}=\varsigma / \Delta \varphi \\
\mathrm{P}-\text { value }<\cdot / \cdot \cdot 1\end{array}$} & \multirow[t]{2}{*}{$V / T /$} & \multirow[t]{2}{*}{$9 / \vee 9$} & $F / Q V$ & $r V / T$ & عزت نفس قبل آموزش \\
\hline & & & $f / 19$ & Fq/ar & عزت نفس بعد از آموزش \\
\hline & \multirow{3}{*}{$1 \cdot 1 \cdot r$} & \multirow{3}{*}{$-19 / 79$} & $\Delta / \Delta F$ & $q \cdot / r q$ & اضطراب قبل از آموزش \\
\hline $\begin{array}{c}\mathrm{T}=-9 / 9 \mathrm{~V} \\
\text { P-value }<\cdot / \cdot \cdot 1\end{array}$ & & & $V / T I$ & $V \cdot / \Delta \cdot$ & اضطراب بعد از آموزش \\
\hline \multirow{2}{*}{$\begin{array}{c}T=-9 / \wedge) \\
\text { P-value }<\cdot / \cdot \cdot 1\end{array}$} & & & $V / \& \mu$ & $11 r / r q$ & مهارت بالينى قبل از \\
\hline & $11 / \mathrm{AF}$ & - & $11 / \mathrm{V} 1$ & (148 & مههارت بالينى بعد از \\
\hline
\end{tabular}

جدول r. تعيين و مقايسه ميانكين نمره عزت نفس دانشجويان در دو دوره آموزشى منتورشيب و مربى

\begin{tabular}{|c|c|c|c|c|}
\hline مقدار احتمال & Tقدار آماره T T & انحر اف معيار & ميانگين & روش آموزش \\
\hline \multirow{2}{*}{$\mathrm{P}$-value $=\cdot / \cdot 10$} & \multirow{2}{*}{$-r / \Delta T$} & F/gT & $\mathrm{Fr} / \mathrm{V}$ & عزت نفس(كروه مربى) \\
\hline & & $4 / 19$ & f\&/9T & عزت نفس (كروه منتورشيب) \\
\hline \multirow{2}{*}{$\mathrm{P}$-value $<\cdot / \cdot .1$} & \multirow[t]{2}{*}{$11 / 9$} & $11 / \Delta V$ & $1 \cdot r / 9 T$ & اضطراب (كروه مربى) \\
\hline & & $V / T 1$ & $v \cdot 10$ & اضطراب (كروه منتورشيب) \\
\hline \multirow{2}{*}{$\mathrm{P}$-value $<\cdot / \cdot \cdot 1$} & \multirow{2}{*}{$11 / \sqrt{ } 9$} & $F / \Delta V$ & I. D/Ar & مهارت بالينى(كروه مربى) \\
\hline & & $11 / \mathrm{V} 1$ & Irs & ههارت بالينى (كروه منتورشيب) \\
\hline
\end{tabular}

بص

منتورشي) بر ميزان عزتنفس دانشجويان يرستارى در دانشكاه

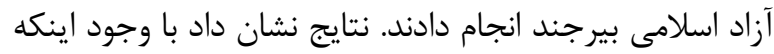

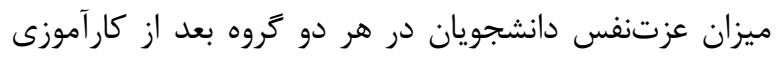

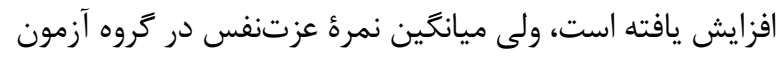
از كروه كنترل بيشتر بود و بر اساس آزمون تى مستقل، اختلاف

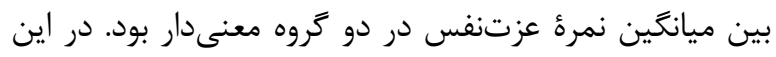

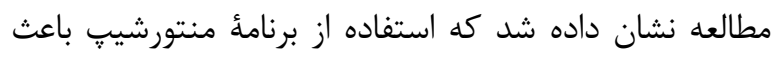

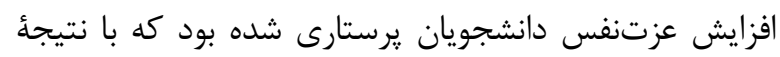

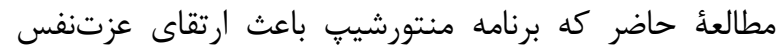

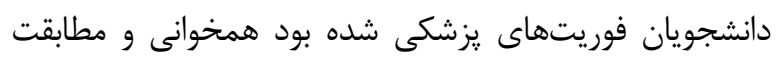
دارد [بr]. - دان. از يافتههاى ديكر اين مطالعه، بررسى ميزان اضطراب قبل و

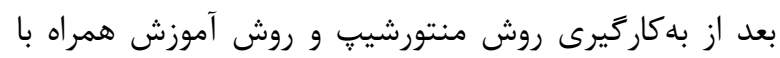

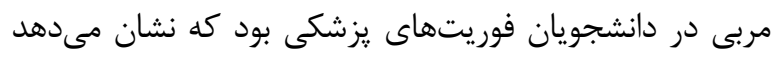

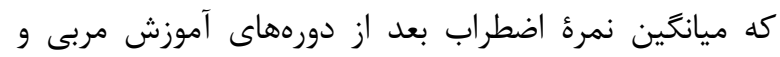

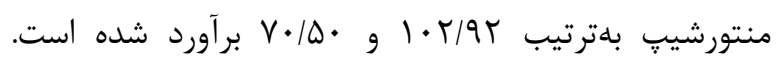

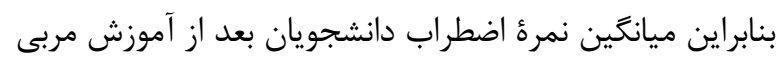

يزوهش حاضر با هدف كلى" بررسى تأثير بهكاركيرى روش

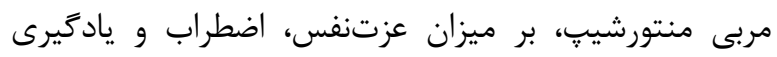

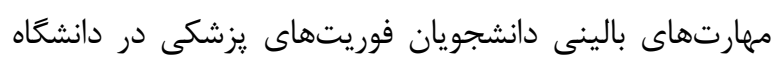
علوميزشكى دزفول ه انجام شد.

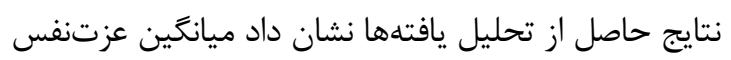

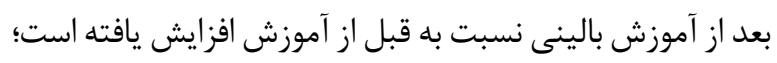

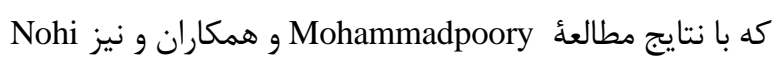

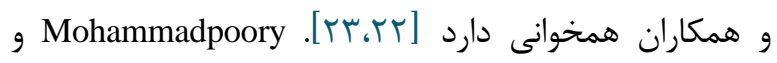

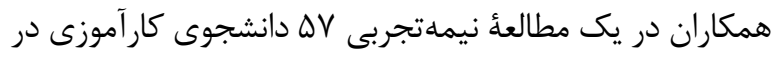

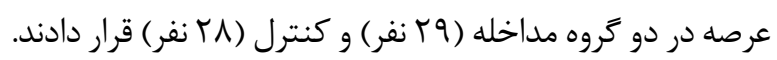

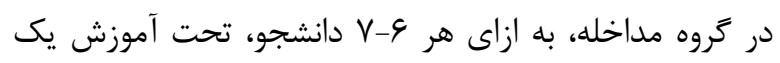

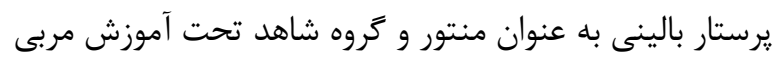

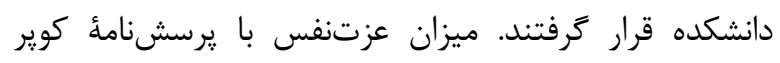

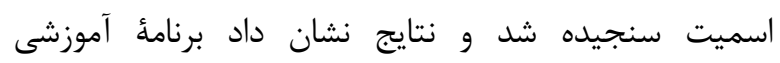

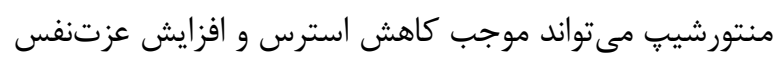

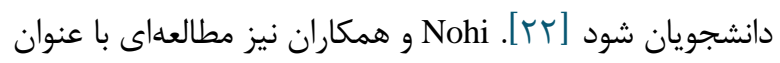
تأثير به كاركيرى دانشجويان عرصه در تيم آموزش بالينى (طرح

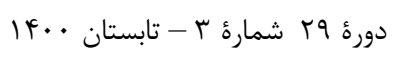

$$
\text { مجله مراقبت يرستارى و مامايى ابنسينا }
$$


مهارت بالينى بعد از آموزش به روش مدل منتورشيٍ است.

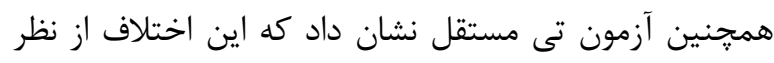

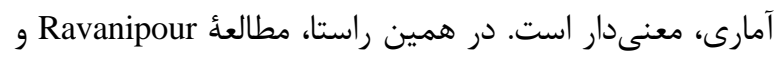

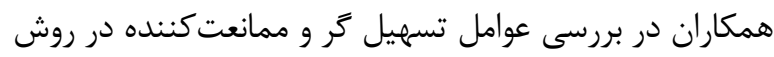
منتورشيٍ دانشجويان يرستارى نشان داد، آموزش و يادكيرى

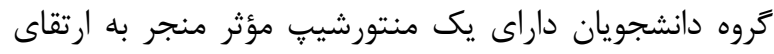

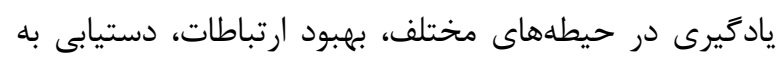

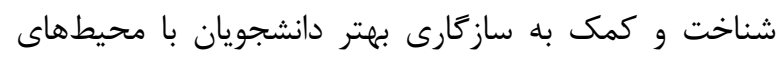

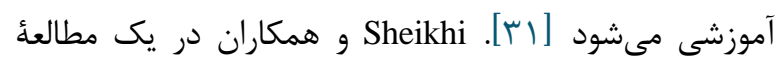

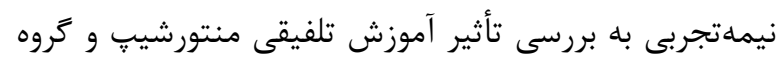

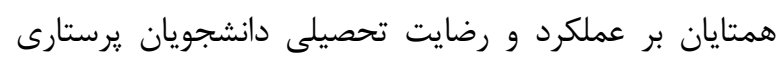

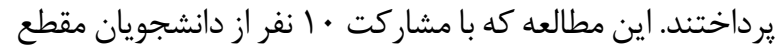

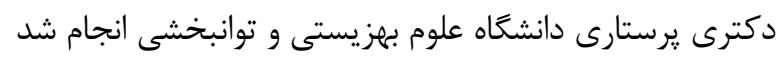

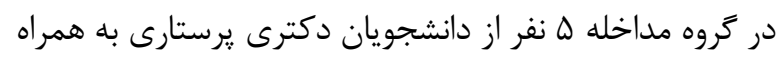
استاد راهنما (منتور) در جلسات مشترك كروه همتايان به مدات

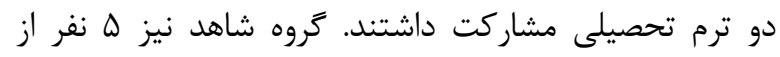

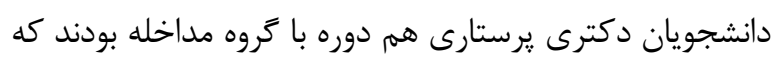

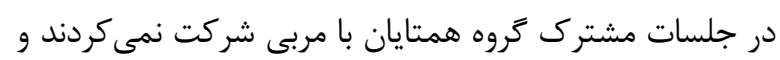

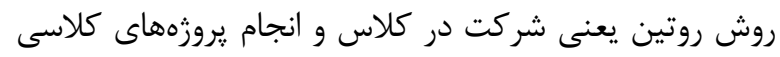

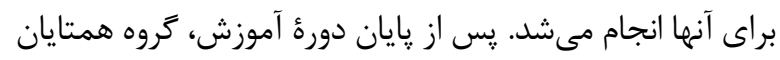

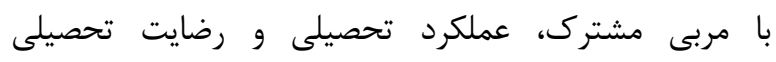

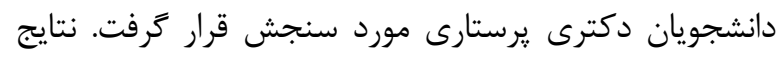

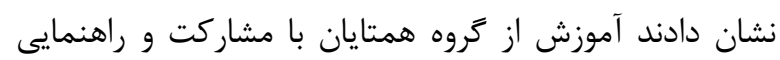

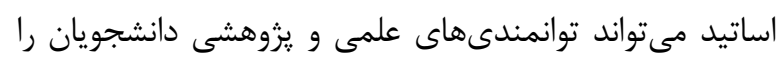
افزايش داده و منجر به توسعأُ عملكرد تحصيلى و كسب رونائ رضايت تحصيلى بيشترى در دانشجويان مقاطع تحصيلات تكميلى شود

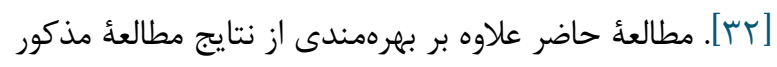

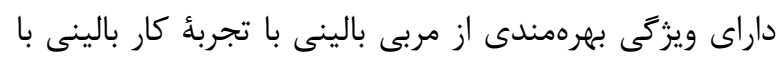

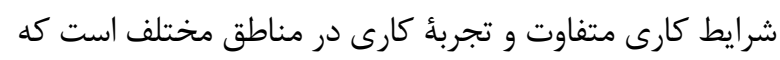
سبب شد دانشجويان اذعان كنند كه استفاده از تجربيات كارى دارى

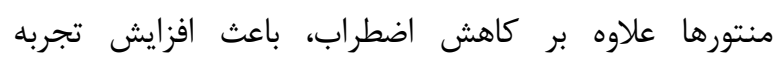

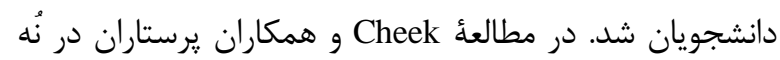

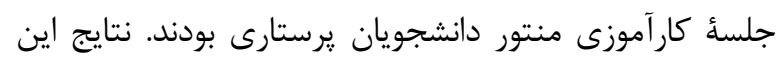

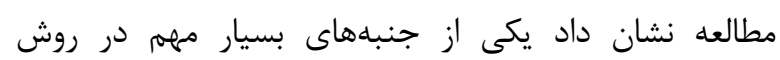

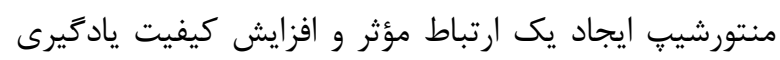

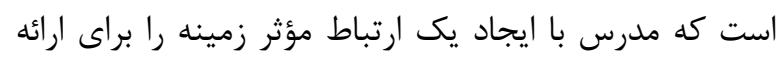

دادن فيدبك مؤثر فراهم مى كند إسجاد بك ارتباط مؤر
بيشتر از ميانكين نمرءٔ اضطراب بعد از آموزش منتورشيٍ است.

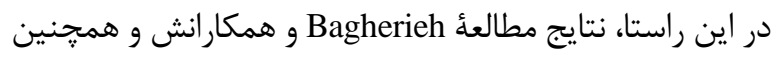

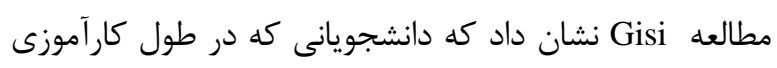

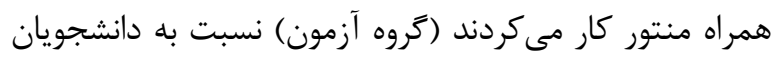

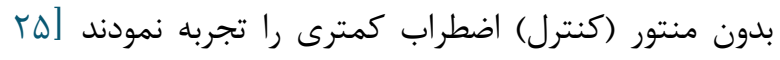

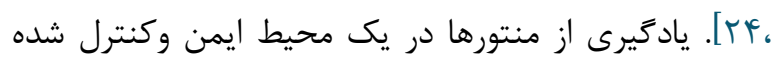
باعث تمايل بيشتر دانشجويان به فرآيند يادكيرى و و كاهش ونش

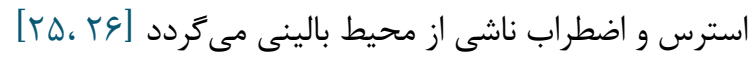

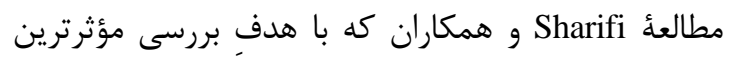

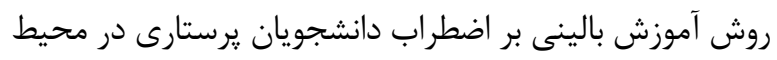

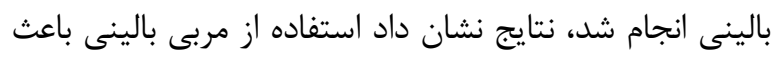

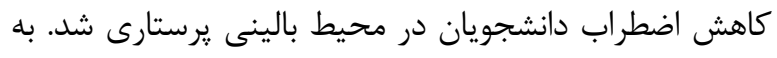

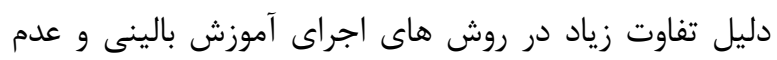

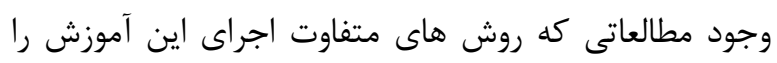

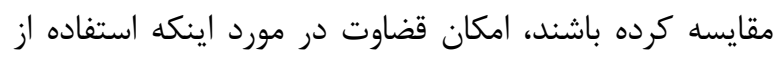

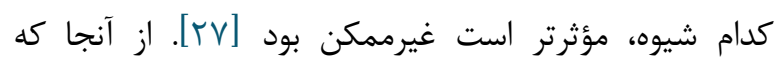

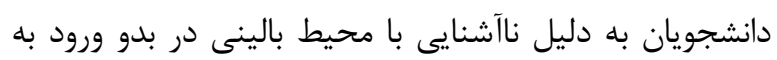

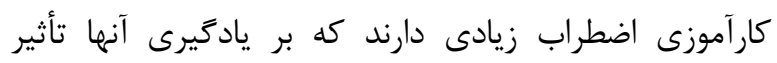

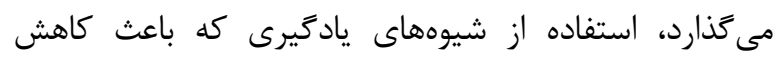

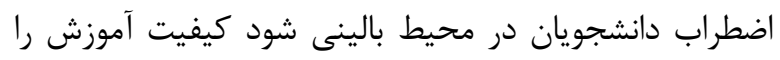

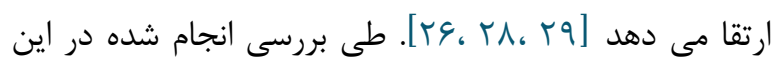

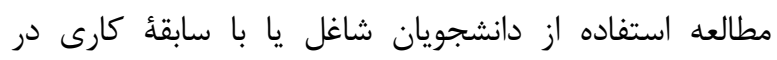

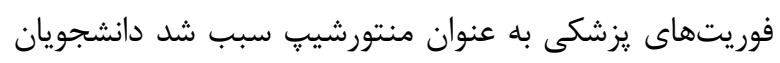

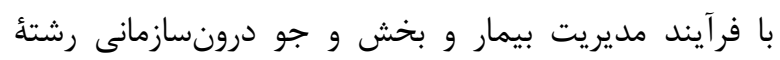

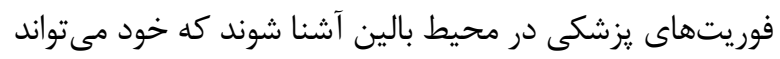

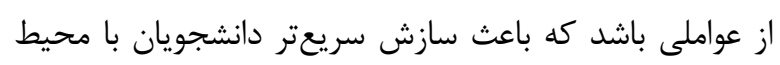

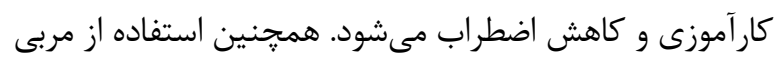

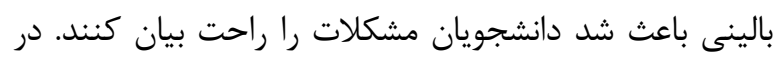

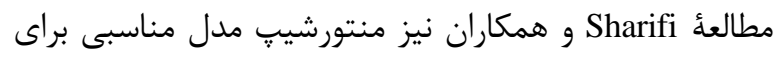

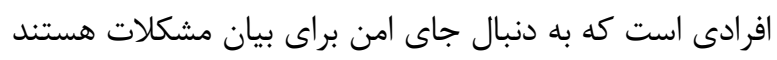

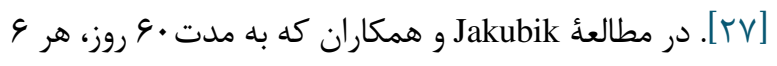

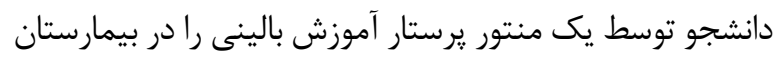

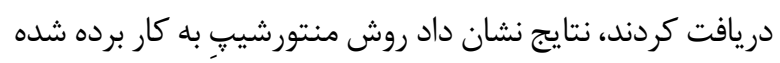

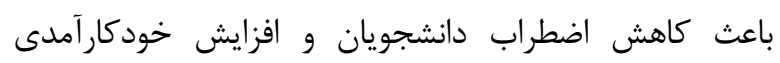

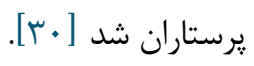

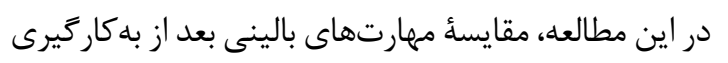

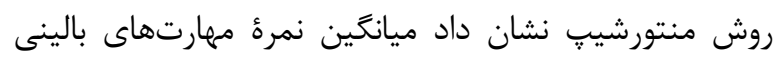

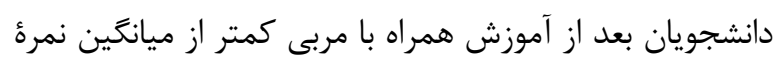


در دسترس بودن دادهها

دادههاى مورد استفاده، در صورت درخواست از نويسنده

$$
\text { مربوطه، در دسترس است. }
$$

$$
\text { منافع رقابتى }
$$

نويسندگان اعلام كردند كه هيج منافع رقابتى ندارند.

$$
\text { سياسگز ارى }
$$

نويسند دانشگاه علوميزشكى دزفول، دانشخاه آزاد اسلامى واحد دزفول

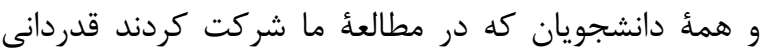
مى كنند.

$$
\text { مشار كت نويسند }
$$

امين عبدالوند، فردوس : يلارك، سميه مهدوى كيان، حميده مشعلجى، مرتضى حبيبى مقدم و طيبه ماهور در

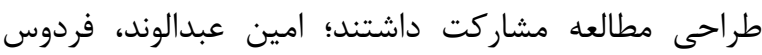

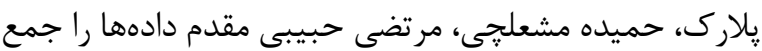
آورى كرده و طيبه ماهور، سميه مهدوى كيان، و مرتضى حبيبى مقدم تحليل كردند. گزارش و مقاله نهايى توسط همةٔ نويسند Fان نوشته شده و همأ نويسند تأييد كردهاند.

$$
\text { تعارض در منافع }
$$

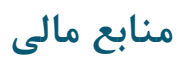

بودجه اين مطالعه توسط دانشعاه علوميزشكى دزفول تأمين
از محدوديتهاى اين يزوهش مىتوان به حجم كم نمونهها و عدم يِيَيرى دانشجويان بعد از فارغ التحصيلى اشاره كرد. همجنين رفتار نامناسب برخى همراهان بيمار و اعتمادنداشتن به دانشجو در صحنهُ حادثه از ديخر محدوديتهاى مطالعه بود كه احتمال مىرود بر عزتنفس و اضطراب دانشجو تأثير گذار باشد كه خارج از كنترل يزوهشگران بود.

$$
\text { نتيجه گَيرى }
$$

يافتهاى اين مطالعه نشان داد به كارگيرى شيوه آموزشى

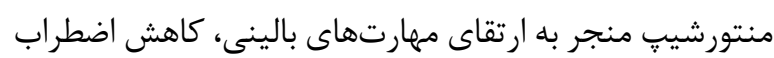
و افزايش عزتنفس دانشجويان مىشود، با توجه به اهميت آموزش بالينى در فوريتهاى يزشكى و اينكه دانشجويان كاردانى فوريتهاى يزشكى بايد قادر باشند كه در مدت كوتاه،

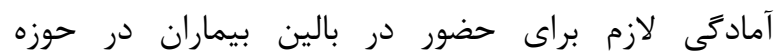
ييشبيمارستانى كسب كنند، ضرورت دارد با اجراى روش هاى جديد و مقرون به صرفه جهت ارتقاى كيفيت آموزش بالينى آنها اقدام نمود. روش منتورشيب يك روش دانشجو محور است و به عنوان يك استراتثى مشاركتى مؤثر مىتواند موجب افزايش توانمندى دانشجويان شود. بنابراين ضرورى است كه

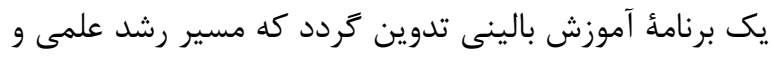
بستر مناسب جهت كسب توانايىهاى بالينى در فراخيران فراهم گردد كه اين خود مىتواند رسيدن به سطح آمادگى مطلوب را براى دانشجويان جهت حضور در بالين تسريع بخشد. اميد است با به كار بستن نتايج اين مطالعه بتوان مربيان

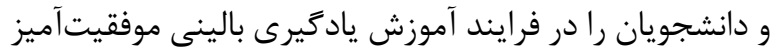

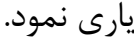

$$
\text { رضايت براى انتشار }
$$
ما رضايت كتبى آكاهانه را از همة شركت كنندكان كسب كرديم.

\section{References}

1. Massey D, Byrne J, Higgins N, Weeks B, Shuker M-A, Coyne E, et al. Enhancing OSCE preparedness with video exemplars in undergraduate nursing students. A mixed method study. Nurs Educ Today. 2017; 54:56-61. [DOI:10.1016/j.nedt.2017.02.024] [PMID]

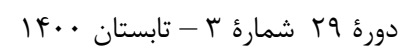

2. Norouzinia R, Ahmadi M, Seidabadi M. Knowledge and Clinical Competence of Medical Emergencies Students in Facing Trauma. Iran J Emerg Med. 2016; 3(2):73-7.

3. Kaufman DM, Mann KV, Muijtjens AM, van der Vleuten CP. A comparison of standard-setting

$$
\text { مجله مراقبت يرستارى و مامايى ابنسينا }
$$




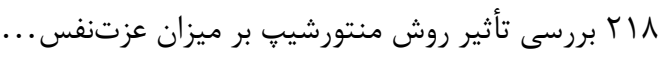

procedures for an OSCE in undergraduate medical education. Acad Med. 2000; 75(3):267-71. [DOI: 10.1097/00001888-200003000-00018] [PMID]

4. Mohammadpoory Z, Hosseini MA, Abbasi A, Biglarian A, Khankeh H. The Effect of Mentorship on Stress of Nursing Students on clinical settings. J Nurs Educ. 2017; 6(3):31-6. [DOI:10.21859/ine-06035]

5. Lavoie-Tremblay M, Sanzone L, Aubé T, Bigras C, Cyr G, Primeau G. A university/healthcare institution mentorship programme: Improving transition to practice for students. J Nurs Manag. 2020;

28(3):586-94 [DOI:10.1111/jonm.12960] [PMID]

6. Heydari H, Kamran A, Mohammady R, Hosseinabadi R. The experiences of nursing students of the mentorship program: a qualitative study. 2012; Health Sys Res. 8(3):438-448.

7. Bagheri M, Sadeghnezhad M, Sayyadee T, Hajiabadi F. The Effect of Direct Observation of Procedural Skills (DOPS) Evaluation Method on Learning Clinical Skills among Emergency Medicine Students. Iran J Med Educ. 2014; 13(12):1073-81.

8. Johnson G, Reynard K. Assessment of an objective structured clinical examination (OSCE) for undergraduate students in accident and emergency medicine. Emerg Med J. 1994; 11(4):223-6. [DOI:10.1136/emj.11.4.223] [PMID] [PMCID]

9. Nelson N, Lim F, Navarra AM, Rodriguez K, Stimpfel AW, Slater LZ. Faculty and student perspectives on mentorship in a nursing honors program. Nurs Educ Pers. 2018; 39(1):29-31. [DOI: 10.1097/01.NEP.0000000000000197] [PMID]

10. Nohi E, HelalBirjandi M, Borhani F, Ahrari Khalaf V. Effect of clinical team teaching (mentorship program) on educational satisfaction of nursing students in Imam Reza Hospital of Birjand 2012. J Med Educ Dev. 2015;9(4):36-45.

11. Vandal N, Leung K, Sanzone L, Filion F, Tsimicalis A, Lang A. Exploring the student peer mentor's experience in a nursing peer mentorship program. J Nurs Educ. 2018; 57(7):422-5. [DOI:10.3928/01484834-20180618-07] [PMID]

12. Eller LS, Lev EL, Feurer A. Key components of an effective mentoring relationship: A qualitative study. Nurs Educ Today. 2014;34(5):815-20. [DOI:10.1016/j.nedt.2013.07.020] [PMID] [PMCID]

13. McCarey M, Barr T, Rattray J. Predictors of academic performance in a cohort of preregistration nursing students. Nurs Educ Today. 2007; 27(4):357-64 [DOI:10.1016/j.nedt.2006.05.017] [PMID]

14. Babaei M, Fadakar Soghe R, Sheikhol-Eslami F, Kazemnejad Leili E. Survey self esteem and its relevant factors among high school students. J Hol Nurs Midwifery. 2015;25(3):1-8.

15. Relationship between introvert and extrovert character, self-esteem and perceived stress with a tendency towards addiction. Rooyesh-eRavanshenasi. 2018; 7(7):261-74.

16. Gholami Booreng F, Mahram B, Kareshki H. Construction and Validation of a Scale of Research Anxiety for Students. Iran J Psych Clin Psych. 2017; 23(1):78-93. [DOI:10.18869/nirp.ijpcp.23.1.78]

17. Khanipour H, Mohammadkhani P, Tabatabaei S. Thought control strategies and trait anxiety: predictors of pathological worry in non-clinical sample. Int J Behav Sci. 2011; 5(2):173-8.

18. Truppman Lattie D, Nehoff H, Neehoff S, Gray A, Glue P. Anxiolytic effects of acute and maintenance ketamine, as assessed by the Fear Questionnaire subscales and the Spielberger State Anxiety Rating Scale. J Psychopharm. 2020:0269881120953991.

[DOI:10.1177/0269881120953991] [PMID]

19. Buela-Casal G, Guillén-Riquelme A. Short form of the Spanish adaptation of the State-Trait Anxiety Inventory. Int J Clin Health Psych. 2017; 17(3):261-8 [DOI:10.1016/j.ijchp.2017.07.003] [PMID] [PMCID]

20. Upadhayay N. Clinical training in medical students during preclinical years in the skill lab. Adv Med Educ Pract. 2017;8:189. [DOI:10.2147/AMEP.S130367] [PMID] [PMCID]

21. Houpy JC, Lee WW, Woodruff JN, Pincavage AT. Medical student resilience and stressful clinical events during clinical training. Med Educ Online. 2017; 22(1):1320187. [DOI:10.1080/10872981.2017.1320187] [PMID] [PMCID]

22. Mohammadpoory Z, Hosseini MA, Abbasi A, Biglarian A, Khankeh H. The Effect of Mentorship on Stress of Nursing Students. J Nurs Educ. 2017; 6(3):31-6. [DOI: 10.21859/ine-06035]

23. Nohi E, Borhani F, HelalBirjandi M. Effect of usingnursing field students in clinical teachingteam (mentorship program) on the selfconfidence of nursing students. Mod Care J. 2013; 10(1): 19-25.

24. Bagherieh F, Khalkhali H. The effect of peer mentoring program on nursing students' stressors in clinical environment. Iran J Med Educ. 2013; 13(4):280-90.

25. Gisi BA. Influence of peer mentorship on nursing education and student attrition. 2011.

26. Walker D, Verklan T. Peer mentoring during practicum to reduce anxiety in first-semester nursing students. J Nurs Educ. 2016; 55(11):6514. [DOI: $10.3928 / 01484834-20161011-08]$ [PMID]

27. Sharifi K, Hosieni F, Adib Hajbagari M. Which peer-based approach reduces the clinical anxiety of nursing students? a review study. J Urmia Nurs Midwifery Fac. 2019;16(11):822-31.

28. Sprengel AD, Job L. Reducing student anxiety by using clinical peer mentoring with beginning nursing students. Nurs Educ. 2004;29(6):246-50. [DOI: 10.1097/00006223-200411000-00010] [PMID]

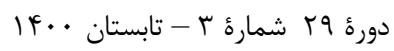


29. Melincavage SM. Student nurses' experiences of anxiety in the clinical setting. Nurs Educ Today. 2011; 31(8):785-9. [DOI:10.1016/j.nedt.2011.05.007] [PMID]

30. Jakubik LD, Eliades AB, Weese MM, Huth JJ. Mentoring practice and mentoring benefit 1: welcoming and belonging--an overview and application to practice using mentoring activities. Pediatr Nurs. 2016; 42(2):84-6.

31. Ravanipour M, Bahreini M, Vahedparast $H$. Facilitators and Barriers in application of peer learning in clinical education according to nursing students. Iran J Med Educ. 2012; 11(6):569-79.

32. Sheikhi M, Fallahi-Khoshknab M, Rahgozar M. The Effect of integration of Mentorshiping and Peer Education methods on the academic Performance and academic Satisfaction in Nursing PhD Students. J Nurs Educ. 2019; 7(5):52-8.

33. Cheek RE, Dotson JAW, Ogilvie LA. Continuing education for mentors and a mentoring program for RN-to-BSN students. J Contin Educ Nurs. 2016; 47(6):272-7. [DOI:10.3928/0022012420160518-09] [PMID] 